she carries a gene which makes her susceptible to poliomyelitis. The homeless, alcoholics, drug addicts and prostitutes which make up the 'skid row' populations of North America have, it appears, been augmented by genebums, those whose perceived genetic shortcomings make them unemployable. They are described as thin, eating their meals from 'dumpsters' and obtaining occasional 'gruntwork', whatever this may mean. Much of what follows is written in the same style. It contains a great deal of information, at least some of it in language which should be comprehensible to the general reader. But overall it presents a rather disjointed and fragmented account of the story, much of which seems to have been gleaned from talking to some of the major players in the field, nearly all of them American. On the other hand it undoubtedly catches some of the political, commercial and scientific tension which has characterised the early years of this extraordinary project.

There is widespread concern about the ethical issues which might arise from the new genetics. Hence they must be debated openly between the scientific world and the public. It is important, therefore, that good popular science writing makes these complex issues available to a wide readership. Those who can stomach the style of this book may find parts of it helpful in defining these difficult issues. Where it seems to fail, however, is in its lack of a cool and dispassionate account of the enormous medical advances which could follow from the human genome project, weighed against these ethical concerns. And it does not make it clear that most of these concerns are not fundamentally new but have simply been highlighted by recombinant DNA technology. In an attempt to catch the reader's attention and describe the more lurid aspects of this endeavour, the book lacks balance. There are better accounts of the genome project for the non-specialist who wishes to try to understand its complexities.

PROFESSOR SIR DAVID WEATHERALL, FRS

Honorary Director, Institute of Molecular Medicine, University of Oxford, John Radcliffe Hospital, Oxford.

\section{The Human Body and the Law}

David Meyers, 367 pages, Edinburgh,
1991, Edinburgh University Press, $£ 45.00$

In 1970 Meyers's book The Human Body and the Law was published. Some twenty-one years later $\mathrm{Mr}$ Meyers has brought out a second edition of his book. In the intervening period there has been an explosion in publication in the medico-legal field. The question arises: is there room for yet another book? The Human Body and the Law covers many of the topics already dealt with in those books presently available consent to treatment, children and incompetent patients, transexualism, abortion, reproductive technology, the severely damaged neonate, termination of life-saving treatment, allocation of resources and experimentation. What then is the value of this book to the student and to the academic? The short answer is that it may be of assistance to both as long as neither has unrealistic aspirations regarding the scope of the book. Those looking for detailed ethical, historical and sociological debate will not find it here. As the author comments, the book is largely a summary of the legal developments in the area since his last edition.

A major strength of the book is the comparative approach that it adopts. The author examines English, Scottish and United States law. Academics are often cautious in introducing students to source materials from other jurisdictions. Unless carefully handled, comparative analysis of medico-legal issues can confuse rather than enlighten the reader. Mr Meyers ensures there is no chance of confusion by outlining the approach taken in each jurisdiction within a separate section inside each chapter. The book also includes chapters in which the issues of transsexualism and the conflicting rights of mother and fetus are examined in greater depth than is attempted in existing textbooks.

A hazard which faces authors who write in this area is that the subject is constantly changing, with new developments both in law and in medical practice. If publication of a book occurs at the wrong time then parts of the book may be swiftly out of date. $\mathrm{Mr}$ Meyers has been unfortunate in this respect. The book was published prior to the Human Fertilisation and Embryology Act 1990 and thus the chapters on reproductive technology and abortion require amendment. Similarly the book also preceded cases such as $\operatorname{Re} \mathcal{f}$ concerning the involvement of the courts with the treatment of the severely damaged neonate.

The Human Body and the Law is a scholarly work which provides a stimulating coverage of the subject. Its niche in the market may, however, be rather in the category of a reference book than as a standard text - an impression reinforced by the price of $£ 45.00$ !

J V MCHALE Department of Law, University of Nottingham.

\section{The Patient- Physician Relation: The Patient as Partner, Part 2}

\section{Robert M Veatch, 306 pages, Bloomington and Indianapolis, 1991, Indiana University Press, $£ 27.50$ hc.}

This is an excellent sequel to the author's The Patient as Partner, which was in turn based on his more theoretical $A$ Theory of Medical Ethics In The Patient as Partner he explored the importance of the role of the patient as an active partner in medical research. In the present volume he extends his argument to the setting of clinical care.

The book is well-structured in five parts covering foundational issues, the individual professional-patient relationship, the social counterpart of this relationship, specific problem areas, and future directions. The coverage is impressive, from basic moral and political theory, through topics as diverse as malpractice, experimental drugs, placebos, cost containment, the elderly, organ transplantation, guardianship and ethics committees, to a broad picture of clinical practice in a post-modern age. Much of the material has been published before. But it has all been extensively revised and several of the chapters are completely new. Helpful summaries of the author's earlier work are included. The overall result is a clear and coherent synthesis of a mature theory of the doctor-patient relationship.

The central theme of the book is that patients and their surrogates should be recognised fully as active partners in the process of clinical decision-making. At one level this is no more than a restatement of the importance of the principle of autonomy in medical ethics. But the author derives his model of the doctor-patient relationship from a 
detailed contractual theory of professional relationships in which the patient has definite duties as well as rights. This is not a new idea. The author quotes the American Medical Association's first code of ethics which included no less than eight positive obligations on the patient. Modern medical ethics, though, is largely doctor-centred, emphasising his or her duties - of veracity, confidentiality, justice and so forth - and the corresponding rights of the patient. In the author's contractual model, on the other hand, equal importance is attached to the duties of the patient many of which indeed mirror the doctor's duties - and the corresponding rights of the doctor.

There is also an interesting subtheme. The author is among those who have emphasised the way in which value judgements are woven into the very heart of clinical decision-making. Most doctors, notwithstanding the insights of philosophers and sociologists, still hold an essentially scientific view of medicine, believing that a large majority of clinical decisions are based on purely technical considerations. But all decisions issuing in action involve values as well as facts. And this leads directly to the contractual model, the values relevant to clinical decisions being at least as much those of the patient as the doctor. It also leads to the author's vision of the future of medicine. Recent work in the philosophy of science has shown that science itself is embedded in a complex nexus of personal and social values. In his concluding chapter the author indicates how this post-modern understanding of science could transform every aspect of the traditional relationship between doctor and patient.

This sub-theme is important. The author claims, rightly, that his contractual model is a counter-balance to the arrogance of technological medicine. But it could be said of his book that it illustrates one of the pitfalls of bioethics - the danger as Priscilla Alderson has put it, that patients will be 'recreated doubly as lay people' (1), originally by technical experts, and now by a new breed of ethical experts. The language of contract reinforces this. The author's recommendations on resuscitation orders, for example, although pithy and practical, read like a legal textbook. And in the section on patients' duties, was it really necessary to put the obligation to pay the doctor's fees in top position? The issues here are well illustrated by psychiatric ethics. Along with much of the bioethics literature, this is the one glaring gap in the book's coverage. It is there by implication, of course. But in psychiatry, above all, the evaluative element in clinical decision-making is transparent. And in psychiatry, above all, while legal safeguards on autonomy are essential, we need a return to caring, to that nurturing engagement with the patient's experience and values for which Priscilla Alderson argues.

But these cavils are mainly against bioethics in general. This book is vigorous, detailed, well-argued and original. It is a timely contribution to scholarly debate on the relationship between doctor and patient.

\section{Reference}

(1) Alderson P. Choosing for children: parents' consent to surgery. Oxford: Oxford University Press, 1990.

K W M FULFORD,

Research Psychiatrist, Department of Psychiatry, University of Oxford, Warneford Hospital, Oxford $O X 37 \mathcal{Y X}$.

\section{Global \\ Responsibility: in Search of a New World Ethic}

Hans Küng, xix + 158 pages, London, 1991, SCM Press, £12.95.

Why should this book be reviewed in the JME? Something needs to be said about its author and contents before facing this question. Hans Küng is fundamentally a systematic theologian who has established a formidable reputation for learning and liveliness of mind. His books have been widely read, and he was a consultant at the Second Vatican Council (1962-5). In 1963, at the age of 35 , he had already been appointed Professor of Dogmatic and Ecumenical Research and Director of the Institute for Ecumenical Research at the University of Tübingen. Subsequently the Vatican withdrew his credentials as an 'official' teacher of Roman Catholic theology, and from 1980 he has held an independent chair in Ecumenical Theology at Tübingen, whilst continuing as a Director of the Institute.

Since then his interests have widened beyond the internal concerns of the Christian Churches, though not excluding them. In this book, which is the herald of a trilogy on Judaism, Christianity and Islam, he produces a manifesto on the following three themes: (1) No human life together without a world ethic for the nations; (2) No peace among the nations without peace among the religions; (3) No peace among the religions without dialogue among the religions. His sense of urgency is as great as that behind The Communist Manifesto in 1848, and better founded. It has led to a great effort to write clearly and untechnically in a way that any educated person can understand. He breaks down the argument with many summaries and signposts. Technical support for them comes in the footnotes.

He presents the need in our postmodern and plural world for a minimum of common values, norms and attitudes, and for an ethic of responsibility, in the double sense of accountability and concern for the truly human. He argues that an ethical relativity in understanding the details of human life does not mean a total relativism. In particular the humanum is not just a 'Western' invention. He finds the seeds of it in all the great religions, but a good deal more besides; and if they are to promote it they need much self-criticism before they can be true to their best. (He does not advocate syncretism.) They will need to exhibit a middle way between legalism and libertinism. To do this they must be in dialogue. Küng explores the basis on which such dialogue can be undertaken.

But why bother about religion? One aim of the book is to argue that ethics does need religion, that the Unconditioned can best sustain the changing and conditioned features of human life. But why should those who are indifferent to religion, or 'cultured despisers' of it, bother with it? Because they should not shut their eyes to the sheer amount of it in the world, and its possibilities for good or evil.

Küng ends by calling for dialogue of many kinds. These include dialogue among and within the professions. Medicine is a profession; it, too, needs a common, human, ethical basis. A purely technological medicine is inhuman and a moral disaster. Medicine cannot afford to assume a common, basic, ethical foundation. Such a foundation has continually to be explored and worked for. Whether or not one agrees with Küng in every detail, he presents a case which needs to be heard. That is why his book is reviewed in the JME.

RONALD PRESTON, Emeritus Professor of Social and Pastoroal Theology, Manchester University. 